The BDJ News section accepts items that include general news, latest research and diary events that interest our readers. Press releases or articles may be edited, and should include a colour photograph if possible. Please direct your correspondence to the News Editor, Arveen Bajaj at the BDJ, 64 Wimpole Street WIG 8YS or by e-mail to bdj@bda.org

\section{New guidelines}

New guidelines for the management of Sjögren's syndrome have recently been produced by a specialist advisory group. Sjögren's is a chronic condition which causes dry eyes and a dry mouth and affects an estimated 500,000 people in the UK.

The guidelines give advice on identifying and managing patients who often present with such diverse symptoms that making a diagnosis is difficult. The guidelines have been developed for secondary care and reflect current best practice. They provide a clear and simple formula for the diagnosis of the condition which is : dry eye + dry mouth $=$ Sjögren's syndrome .

Copies of the draft guidelines for the management of Sjögren's Syndrome in Secondary Care are now available. To request a copy please contact info@sjogrensguidelines.co.uk.

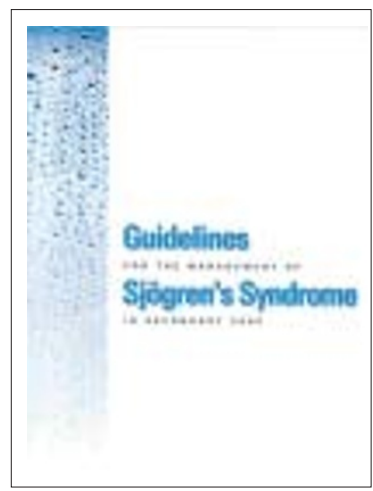

\section{Treatment training}

The Health Development Agency has recently published a 25 page report 'Standard for training in smoking cessation treatments'.

Until now, there has not been a coordinated approach to the content or quality of training in this field. The standard covers three levels of smoking cessation advice, brief interventions, intensive one to one support and advice and group interventions.

Copies are available free of charge from hda@twoten.press.net, ISBN 184279-228-8.

\section{Life saving dogs}

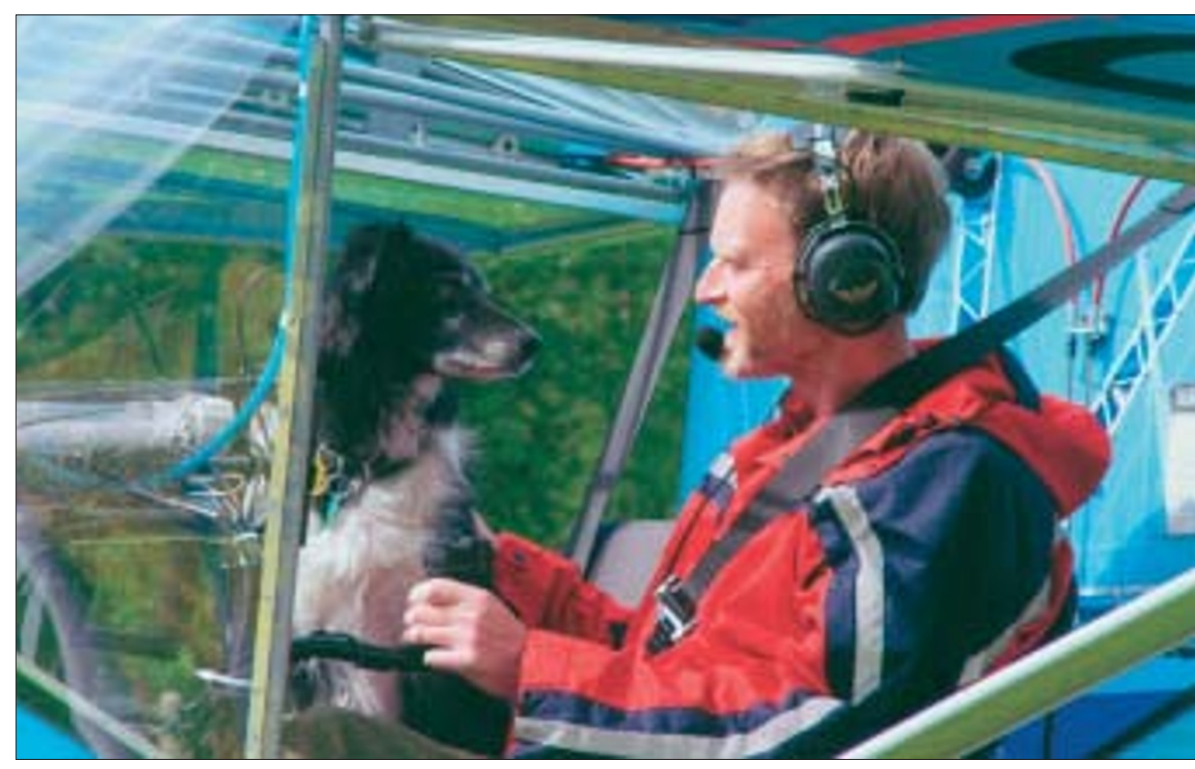

Dentist and search dog handler David Watt flew 1100 miles around the Scottish mainland to raise money for charity in his home-built aeroplane. The Search and Rescue Dog Association (SARDA Lakes) is a voluntary organisation, dedicated to the use of search dogs to assist in search and rescue operations to locate missing persons, predominantly in mountainous environments. For more information visit www.sardalakes.org.uk.

\section{New magazine for the dental team}

The $B D J$ is pleased to launch the first issue of Vital with this issue of the $B D J$

Vital is a new magazine for the dental team, published as a regular supplement to the BDJ. PCDs have increased in importance in recent years and with the extension of duties for hygienists and therapists and the upcoming registration of dental nurses and technicians, the time is right for a publication for the whole dental team.

The launch issue of Vital includes features on GDC registration, the dental nurse NVQ, the status of PCDs, treatment planning and a day in the life of a dental technician.

Vital also includes a lifestyle section, letters, news, advice and opinion. The magazine will be launched officially at this year's Dental Showcase in Birmingham from November 20-22. For additional copies, visit the $B D J$ on stands 03-05.

Alternatively, write to BDA, Freepost

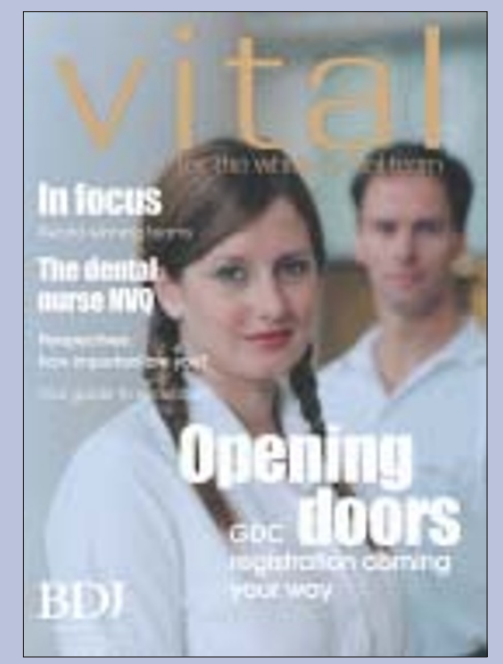

WD574, Vital, Publishing Directorate, British Dental Association, 64 Wimpole Street, London W1E 2UZ or e-mail vital@bda.org. Vital is available on line at www.nature.com/vital. 


\section{DIARY}

November 2003

National Association of Dental Advisers

Conference 2003

Date: 20-21.11.03

Venue: Jurys Bristol Hotel

Contact: Events Office,

British Dental Association

Tel: +44 (0) 2075634590

Fax: +44 (0) 2075634591

E-mail: events@bda.org

SAAD: Advanced Conscious Sedation - The way forward

Date: 29.11 .03

Venue: GDC, London

Contact: SAAD conference

administration

Tel: +44 (0) 2079351656

March 2004

2nd Asia Pacific Congress on Craniofacial

Distraction Osteogenesis

Date: 5-10.03.04

Venue: Maldives

Contact: www.distraction2004.com

E-mail: secretary@distraction2004.com

May 2004

BDA National Annual Conference

Date: 06.05.04 - 08-05.04

Contact: Events Office,

British Dental Association

Venue: Bournemouth International

Centre

Tel: +44 (0) 2075634590

Fax: +44 (0) 2075634591

E-mail: events@bda.org

\section{Practice wins business award}

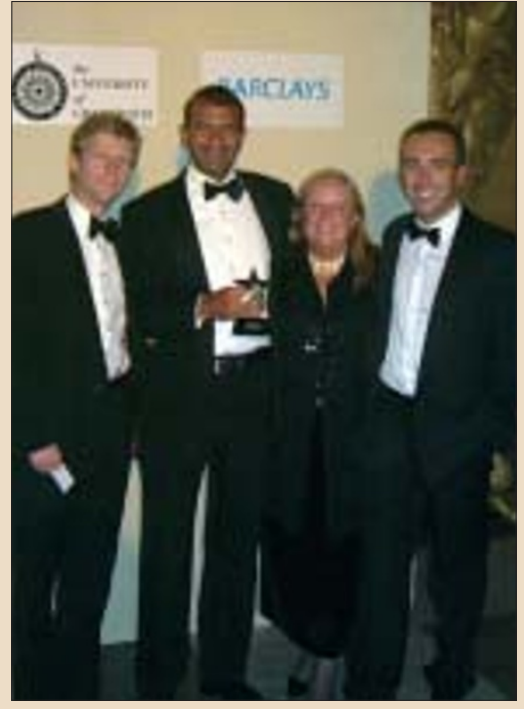

From left to right: Tony Bull, dentist, Neil Sikka, principal, Dee Marsh, operations manager and Rob Fallon, dentist.
Barbican Dental Care (BDC) has become the first dental practice to win the Business Excellence Award, presented by Docklands Business Club, London.

The Business Excellence Award was looking for a strong track record in overall business performance and effectiveness, including sales and profitability, staff involvement and dedication and examples of business excellence in services and/or products.

BDC's principal Neil Sikka believes that key factors in winning the award were BDC's company dental plan (which covers normal yearly dental needs for a monthly fee), a marketing strategy aimed at local companies, a good working environment and high staff retention.

The Awards were made at a gala dinner at The Old Royal Naval College in Greenwich. sponsored by Barclays and judges were

\section{Further recognition for Colchester practice}

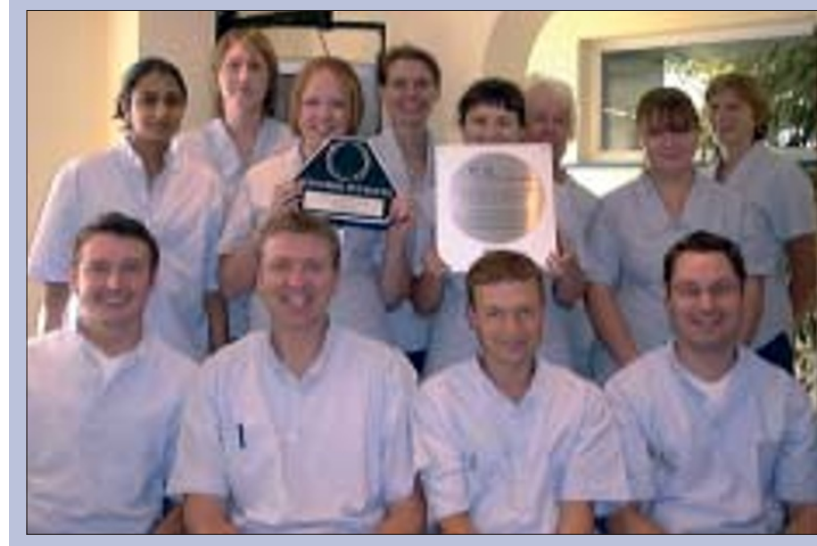

The dental team at Bromley Road Dental Surgery had something to celebrate after being accredited to the BDA's Good Practice Scheme.

The practice was also the first in North Essex to achieve Investors in People status some three years ago and attributes team effort for the success. 


\section{Committed to quality care}

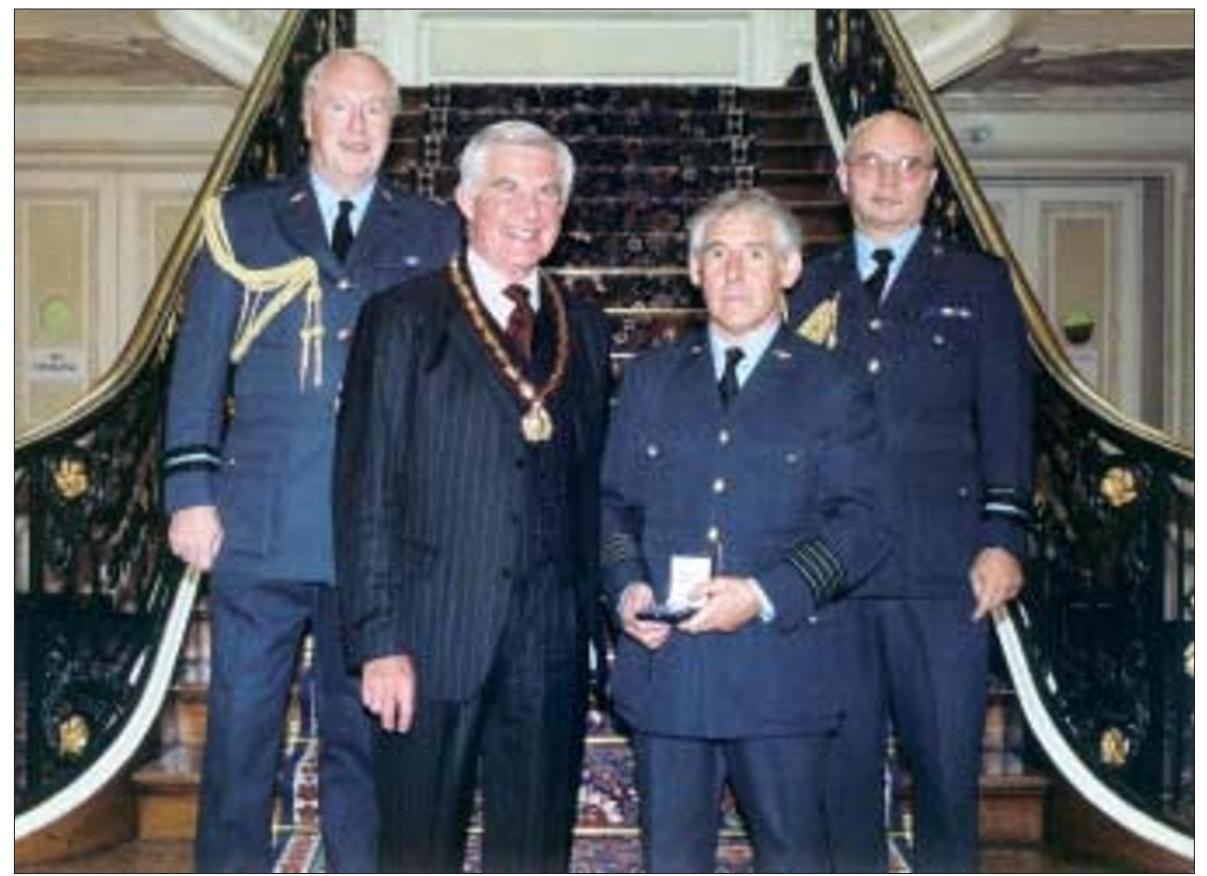

Group Captain Armstrong was awarded the Lean Memorial Award by the RAF Dental Branch in recognition of his consistent commitment to the delivery of high quality dental support to the RAF, for his role in the development of clinical audit and clinical policy in the Defence Dental Agency and his contribution to the wider dental profession as an outstanding ambassador of the RAF. The award was established to

commemorate the life and work of Air Vice-Marshal D A R Lean OBE LDS FBIM RAF who died whilst serving as Director of RAF Dental Services in 1982. The prize is awarded annually to an officer of the RAF Dental Branch who, in the opinion of the management trustees, has made the most or outstanding contribution to the practice of dentistry in the RAF. (Above: Group Captain Armstrong (right) receives the award from Air Vice-Marshal (Retired) I G McIntyre (left). Also present is (far right) Air Vice-Marshal W J Pike Director General Medical Services (RAF) and (far left) Air Commodore J Reid Director Dental Services (RAF).

\section{Former BDA chief executive sadly missed}

Norman Whitehouse, former secretary and Chief Executive of the BDA, died on 10th October.

Dr Whitehouse was Chief Executive between 1986 and 1993, when he left the BDA to take up the post of Dean at the Dental School in Cardiff, where he was also Professor of Dental Public Health.

Earlier this year he was awarded an honorary doctorate from the University of Wales for services to dentistry.

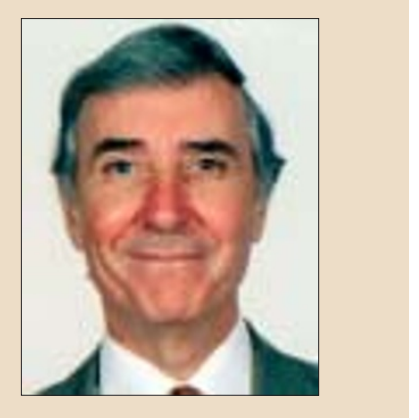

\section{Double liP success for practices}

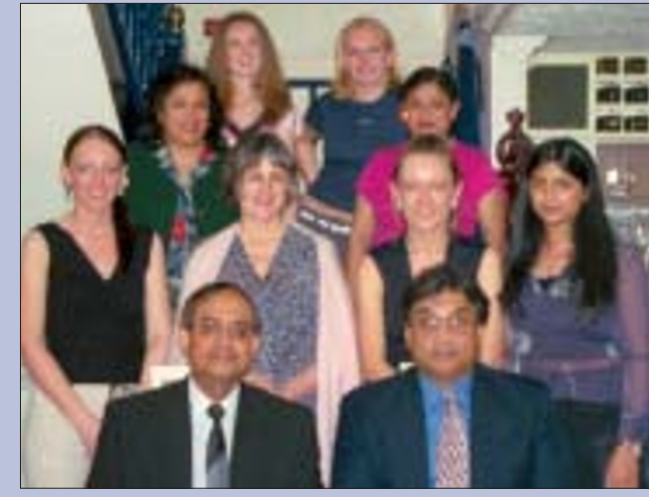

Two dental practices in Woolwich and Sutton have been recognised as an Investor In People.

The practices are owned by Jay and Ravi Patel and the award has enabled all 16 staff to achieve their highest potential.

The Woolwich practice is believed to have been in continuous existence for around 100 years while the Sutton practice moved to its present premises in 1982. 